This PDF is a selection from an out-of-print volume from the National Bureau of Economic Research

Volume Title: Trade and Protectionism, NBER-EASE Volume 2

Volume Author/Editor: Takatoshi Ito and Anne O. Krueger, editors

Volume Publisher: University of Chicago Press

Volume ISBN: 0-226-38668-6

Volume URL: http://www.nber.org/books/ito_93-2

Conference Date: June 19-21, 1991

Publication Date: January 1993

Chapter Title: Economic Growth and Trade Relations: Japanese Performance in Long-Term Perspective

Chapter Author: Gary R. Saxonhouse

Chapter URL: http://www.nber.org/chapters/c8074

Chapter pages in book: (p. $149-182)$ 


\title{
6 \\ Economic Growth and Trade Relations: Japanese Performance in Long-Term Perspective
}

\author{
Gary R. Saxonhouse
}

Since the second half of the nineteenth century, Japan's productivity growth has outstripped that of every other major industrialized economy. This impressive achievement rested on $\mathbf{2 5 0}$ years of growth and structural change prior to the opening of Japan to international trade in the nineteenth century. Japan's superior performance is not the exotic product of a small cluster of distinctive economic institutions. Japan's rapid economic growth has coexisted with labor markets, capital markets, and product markets whose structure and organization have changed radically over time. Japan's economic performance has been successful for far too long for it to be attributable to any one particular configuration of its economic institutions.

The invariance of Japan's economic record to a wide variety of institutional circumstances is important to keep in mind when considering Japan's distinctive trade structure. Japan's rapid economic growth over the past century has gone hand in hand with a very distinctive performance in international trade. What Japan sells to the rest of the world has changed continuously and dramatically over time. At the same time, Japan has long imported a distinctively low level of manufactured imports. There have been facile attempts to link Japan's controversial trade performance with some of Japan's distinctive economic institutions. As with Japan's economic growth, so Japan's trade performance has also been distinctive for too long to be the product of any specific configuration of Japan's product markets and/or factor markets or any particular style of state intervention.

None of this should suggest that Japan's superior economic performance is so deep rooted as to defy economic explanation. Rather, it is important to focus on the real continuities in Japan's experience. In particular, Japan's geography is much different from that of the world's other major industrialized

Gary R. Saxonhouse is professor of economics at the University of Michigan. 
economies. Throughout the past century, relative to these other economies, Japan, while uniquely poorly endowed with natural resources, has also been well endowed with a high-quality labor force and with unusually thrifty households. These distinctive Japanese circumstances may go a long way toward explaining its superior economic growth performance, its meager level of manufactured imports, and its lack of participation in intraindustry trade.

Throughout modern Japanese history, Japan's international trade has been based on the sharp differences in its circumstances from those of the rest of the industrialized world. In recent years, this has put Japan at odds with the rest of the major actors in the global economy. Increasingly, international trade between most major economies is governed by their similarities, not by their differences with each other. Similarities-based trade has none of the politically contentious income redistribution consequences of differences-based trade. Similarities-based trade builds alliances for the further reduction of trade barriers. By contrast, while differences-based trade is the traditional substance of international trade theory, nonetheless it taxes the legitimacy of the international economic system.

In the first two sections of this paper, Japan's distinctive economic performance will be reviewed. In a third section, how well traditional and newer theories of international trade explain Japan's performance will be examined and new statistical tests will be presented. Finally, the implications of the changing pattern of Japanese trade for the past, present, and future of Japan's international economic relations will be discussed.

\subsection{Productivity Growth: Prewar and Postwar}

It is all too easy to forget that the various national economic performances as presently observed may be surprisingly deep rooted. For example, relatively poor American productivity performance is arguably an old, old story and not the result of a sudden loss in American know-how. U.S. productivity growth has been relatively poor, not only for the past fifteen or twenty years, but for the better part of the past century (Maddison 1982, 98; Baumol, Blackman, and Wolff 1989). ${ }^{1}$ Between 1899 and 1913, the U.S. growth rate was already lower than that of Sweden, France, Germany, Italy, and Japan. The U.S. rate of productivity growth was again below all these countries (except for Germany) between 1913 and 1939. While U.S. productivity grew relatively rapidly during both world wars, this is in good part a result of the slowdown in the growth of other countries. And the American experience relative to other countries in the four decades after the Second World War seems to differ only in detail from its experience in the four pre-Second World War decades (see table 6.1).

If there are continuities in American performance, there are certainly con-

1. For a more skeptical view, see Williamson (1991). 
Table 6.1 Comparative Levels of Productivity, 1890-1986 (U.S. GDP per manhour $=100$ )

\begin{tabular}{lrrrr}
\hline & 1890 & 1938 & 1950 & 1986 \\
\hline France & 55 & 64 & 44 & 89 \\
Germany & 58 & 56 & 33 & 79 \\
Italy & 44 & 49 & 32 & 74 \\
Japan & 23 & 33 & 14 & 51 \\
Sweden & 44 & 59 & 55 & 76 \\
United States & 100 & 100 & 100 & 100 \\
\hline
\end{tabular}

Source: Maddison $(1982,98)$ and Maddison $(1989,89)$.

tinuities also present in Japanese economic performance. Between the late 1940s and the mid-1980s, Japan's productivity growth exceeded the performance of every other major economy (World Bank 1986). Not only did Japan's productivity grow faster than each of the OECD economies, but it also grew faster than any of the Latin American economies and faster than such Asian economies as Hong Kong, Korea, Taiwan, and Singapore.

Like the United States, however, Japan's prewar experience resembles its postwar experience. Japan grew faster than any other economy in the postwar period, but it also grew faster than all other major economies during the seven decades between the Meiji Restoration (1868) and 1938 (Maddison 1982). Indeed, Japan's distinctive position can be pushed back still further. Already in the 1870s and 1880s Japan's level of economic accomplishment was well above the rest of Asia. Only in the 1950s and 1960s would other Asian economies reach the levels of performance that Japan had achieved eighty years earlier (Ohkawa 1978). This impressive achievement, in turn, rested on almost three hundred years of growth and structural change prior to the opening of Japan to international trade in the 1850s. While Tokugawa Japan missed the scientific and industrial revolutions of the seventeenth and eighteenth centuries, this by no means necessitated economic stagnation. For example, between 1600 and 1870, Japanese agricultural output grew at an impressive average annual rate of 0.33 percent (Umemura 1973).

It is no simple matter to account precisely for these long-standing differences in U.S. and Japanese productivity performance. There is some reason to believe that, among the countries with the capacity to learn from foreign experience elsewhere, productivity bears a negative relation to the level of productivity performance (Baumol, Blackman, and Wolff 1989). ${ }^{2}$ Following the mid-1890s, the United States had a lower rate of productivity growth than Sweden, France, Germany, Italy, and Japan, but, in the mid-1890s, it already had the world's highest level of productivity. By contrast, among these countries, Japan had by far the lowest level of productivity in the mid-1890s but followed with by far the highest rate of productivity growth. 
With hindsight, it is not surprising that there should be substantial convergence in U.S. and Japanese economic performance. American wealth in the late nineteenth century rested on an abundance of natural resources and a skilled population capable of economically exploiting the latest scientific and technological achievements within the framework of largely accommodating policies of local, state, and national governments (Wright 1990). Despite economic improvement during the Tokugawa period, and despite the comparatively high basic literacy and numeracy of Japan's male population in the late nineteenth century, Japan's familiarity with Western science and technology was still much too limited to overcome its relative dearth of natural resources (Dore 1965).

Over the course of the late nineteenth century and the twentieth century, however, these conditions have changed dramatically. During this period, there has been no significant growth in the size or importance of American natural resource wealth relative to the American population. Growth in natural resource wealth could not push America forward relative to the rest of the world as had happened earlier in the nineteenth century. Quite the contrary. New mineral discoveries in the Middle East, Africa, Latin America, and Australia and transportation improvements in these regions and elsewhere have tangibly diminished natural resources as the basis of twentieth-century American prosperity.

While natural resource wealth has long since ceased to provide the basis for American productivity growth, productivity growth has not stagnated. The growth of America's physical capital stock and new investments in research and development and human resources have continued to raise American productivity. Despite nine decades of relatively slow productivity growth, America's high late nineteenth-century level of productivity and the happy absence of wartime destruction have left the United States, at least as late as the end of the 1980s, with the highest level of aggregate productivity among the world's major economies.

The declining importance of natural resource wealth could only help Japan's relative performance in the twentieth century. Increasing Japanese thrift and increasing Japanese capacity to make use of hitherto remote or unknown foreign advances in science and technology have helped Japan to achieve the twentieth century's highest rate of productivity growth (Ohkawa and Rosovsky 1973). Unhappily, in part because of its very low level of productivity in the late nineteenth century (and hence the very great potential to benefit from foreign information), and in part because of the destruction resulting from Japan's disastrous Pacific war, nine decades of relatively rapid productivity growth have still left Japan with the lowest level of productivity among the world's major industrialized economies (Maddison 1989, 89).

It is useful to be reminded of the persistence of relative national economic performance. For all the fascination that social scientists may have with institutions, relative performance for many economies often seems independent of all but the most radical institutional change. Long before permanent employ- 
ment was a significant element in Japanese management strategy, long before semiannual bonuses were a significant element in Japanese employee compensation, long before stability was the hallmark of Japanese macroeconomic management, and long before high quality was a familiar attribute of Japanese goods, Japanese productivity growth rates were the envy of the world. ${ }^{3}$

When Japanese labor turnover rates in manufacturing were far higher than what was ever experienced in Europe or the United States, when Japanese industry exhibited great creativity in producing unprecedentedly poor-quality products, and when Japanese macroeconomic management bordered on the chaotic, Japan was still able to raise its rate of productivity improvement above what was experienced by other major industralized countries (Saxonhouse 1976; Saxonhouse and Ranis 1985). The available historical evidence suggests that Japan's longtime rapid rate of economic improvement does not rest on a few distinctive institutional arrangements. Japan's superior economic performance has persisted even as its most basic economic institutions have changed markedly. Japan is under pressure in negotiations such as the Structural Impediments Initiative (SII) to harmonize its economic institutions with those of its trading partners (Saxonhouse 1991). On the basis of the past record, there is certainly considerable reason to believe that Japan can absorb such adjustment without much damage to its capacity for continued superior economic performance.

\subsection{Trade and Economic Growth}

It is hard to think about the determinants of long-term national economic performance without considering the role of international economic relations. The classical economics of Smith, Ricardo, and Mill stressed the intimate link between the size of markets and productivity improvement ${ }^{4}$ At an aggregate level, the evidence of the past century is mixed. With the radical exception of Japan, and possibly France, foreign trade declined in importance between the late nineteenth century and the Second World War. During this period, exports grew far more slowly than GNP for most major economies. It is significant that Japan, the country with the highest rate of productivity growth, also experienced continued rapid growth in the role that foreign trade played within its economy. By contrast, as seen in table 6.2, for the rest of the major industralized countries, a decline in the importance of foreign trade did not mean a decline in the rate of productivity growth. Quite the contrary. For example, as noted in table 6.3, during the interwar years, even as foreign trade dropped sharply, productivity growth actually accelerated.

In the decades since 1945, international trade's importance once again re-

3. For an interpretation of Japanese economic performance that stresses bonus payments, permanent employment, and macroeconomic stability, see Weitzman (1984) and Freeman and Weitz$\operatorname{man}(1987)$.

4. Smith's pin factory is the most famous example. 
Table 6.2

Trade and Overall Economic Activity, 1890-1986 $(1890=100)$

\begin{tabular}{|c|c|c|c|c|c|c|}
\hline & \multicolumn{2}{|c|}{1890} & \multicolumn{2}{|c|}{1938} & \multicolumn{2}{|c|}{1986} \\
\hline & Exports & Output & Exports & Output & Exports & Output \\
\hline France & 100 & 100 & 220.9 & 184.4 & $3,585.3$ & 916.4 \\
\hline Germany & 100 & 100 & 193.0 & 347.2 & $2,938.1$ & $1,575.4$ \\
\hline Italy & 100 & 100 & 161.8 & 242.6 & 7.721 .7 & $1,282.8$ \\
\hline Japan & 100 & 100 & $4,426.5$ & 468.8 & $93,278.0$ & $5,341.3$ \\
\hline Sweden & 100 & 100 & 351.8 & 406.5 & $4,108.1$ & $1,982.8$ \\
\hline United States & 100 & 100 & 310.4 & 369.2 & $2,555.2$ & $2,108.7$ \\
\hline
\end{tabular}

Source: Maddison (1982, apps. A, F) and Maddison (1989, app. B).

Table 6.3

Productivity, 1870-1979, GDP per Manhour in 1970 U.S. Relative Prices (\$)

\begin{tabular}{lrrrrrr}
\hline & 1870 & 1890 & 1913 & 1938 & 1950 & 1979 \\
\hline France & .42 & .59 & .90 & 1.69 & 1.85 & 7.11 \\
Germany & .43 & .62 & .95 & 1.47 & 1.40 & 6.93 \\
Italy & .44 & .47 & .72 & 1.28 & 1.37 & 5.83 \\
Japan & .17 & .24 & .37 & .87 & .59 & 4.39 \\
Sweden & .31 & .45 & .83 & 1.55 & 2.34 & 6.71 \\
United States & .70 & 1.06 & 1.67 & 2.62 & 4.25 & 8.28 \\
\hline
\end{tabular}

Source: Maddison (1982, 212).

versed course. Instead of declining, international trade has grown much faster than GNP for all the major industrialized economies. For some but not all of the major industrialized economies, this explosive growth in international trade has gone hand in hand with an acceleration in the rate of productivity increase. This has been true most notably for Japan but also for such countries as France, Germany, and Italy.

What accounts for the varied relation between international trade and economic growth over the course of the last century? In view of the experience since 1945, it may surprise some to learn that, for much of both the nineteenth and the twentieth centuries, many economists believed that, as nations experienced economic growth, trade would grow less important (Cooper 1964). In 1821 , Robert Torrens wrote, "As the several nations of the world advance in wealth and population, the commercial intercourse between them must gradually become less important and beneficial" ([1821] 1965, 288). Torrens found that trade resulted from the exchange of manufactures and raw materials. He argued that, as land became scarcer as a result of population growth, the basis for trade would disappear.

At the turn of the century, Werner Sombart formulated the so-called law of the declining importance of export trade. Sombart claimed that the gradual industrialization of the agricultural countries and the increasing capacity to 
consume on the part of the home market would lead to a reduction of the growth of foreign trade relative to the growth of internal trade and production (Sombart 1903).

Sombart's general outlook was shared by other major figures in economics in the first half of the twentieth century. For all their celebrated differences in macroeconomics, Dennis Robertson and John Maynard Keynes both agreed that foreign trade would be relatively less important in future years. In a widely read essay entitled "The Future of International Trade" written in the 1930s and reprinted approvingly by the American Economic Association a decade later, Robertson wrote that trade would become increasingly less important, partly because economic growth would make it less rewarding, and partly because it would be stifled by restrictive commercial policy introduced to reduce the risks inherent in dealing with foreigners (Robertson 1938). Keynes emphasized demand considerations in his own analysis. Keynes observed that the income elasticity of demand for nontradables is much higher than it is for imported goods. This means that, as incomes rise with economic growth, an ever greater share will be spent on locally produced services (Keynes 1933).

In the postwar period, economists have spent a great deal of theoretical energy investigating how the sources of economic growth, such as technological change and capital accumulation, affect the volume of trade. ${ }^{5}$ Much of this research has been conducted for the elementary case where two countries producing two goods with two inputs trade with each other. In this simple world, as a country accumulates more of its relatively scarce factor of production, its interest in trade declines. Similarly, technological change in an import-competing industry that saves on the use of a scarce factor of production should also encourage a decline in trade. Technological change that saves on a scarce factor in an export industry gives a more complicated result. The factor-saving effect of the technological change should encourage a decline in trade. This effect is opposed, however, by the cost-reducing effect of technological change, which should encourage an expansion of the more efficient export industry. The relative strength of these two forces will in any particular instance determine the net effect on trade of technological change.

The simple framework just presented can be adapted to help examine the role of trade within the American and Japanese economies over the past century. For much of the period before the Second World War, the United States was an importer of products that used unskilled labor intensively and an exporter of products that used natural resource products intensively (Crafts and Thomas 1986; Wright 1990). If technological change was generally labor saving during this period, this should have worked to diminish the significance of trade for the American economy. This trend might have been reinforced by the natural resource-using bias that American technological change in all likeli- 
hood also exhibited during this same period (Wright 1990). As before, this would have happened if the factor-using bias of this technological change was more significant than its cost-reducing effect. Further reinforcement might have come from the historical antitrade bias of demand noted by Keynes.

Unlike the United States during the period before the Second World War, Japan had an abundance of relatively unskilled labor and exported laborintensive products (Yamazawa 1978). During the same period, however, Japan's increasing capacity to make use of imported Western technology resulted in Japanese technological change being strongly labor saving (Ohkawa and Rosovsky 1973). This by itself is probably enough to explain the distinctive role that international trade played within the Japanese economy during the early decades of the twentieth century. Despite international trade becoming relatively less important for all major economies, and despite a dramatic increase in global protectionism, trade became much more important for the Japanese economy during these years. Technological change that made Japan's most abundant resource still more abundant surely accelerated this trend.

\subsection{Intraindustry Trade}

The simplest factor-endowment-based theories of international trade are able to provide some insight into early twentieth-century trends. They are of much less help, however, in explaining the explosion in international trade that has occurred in the four decades since the end of the Second World War. The convergence in income levels and in the availability of capital, skills, and technology among the world's major market economies should have worked to continue to diminish the relative significance of international trade in the postwar period. If countries trade to substitute for what is relatively scarce at home, the more similar countries become, the less basis there is for trade.

Assuming that the sharp reversal of the protectionist trends that dominated international commercial policy in the early decades of the twentieth century is insufficient to explain postwar performance, what significant considerations have been left out of the preceding analysis? In the last decade or so, economists have increasingly appreciated that a large share of international trade is driven by considerations other than simple differences in local scarcities of factors of production such as land, labor, and capital (Helpman and Krugman 1985). In particular, within many industries that are important for international trade, a great variety of goods is produced. Because of scale economies, no country is able to produce the full range of differentiated products within any industry by itself. In this case, two countries could be identical, but there is still a basis for trade. Quite in contrast with interindustry trade, with similar tastes, the more countries resemble each other in their size and their factor endowments, the more differentiated products mutually desired will be produced, and the more beneficial trade will be. 
This new perspective on trade does help explain why international trade has grown more rapidly than production during the postwar period (Helpman 1987). As noted in table 6.4, during the postwar period, the economic conditions of the sixteen nations that dominate international trade have become more equal. This decline in the dispersion of the level of economic performance has gone, as theory predicts, hand in hand with growth in intraindustry trade as a proportion of total trade (Grubel and Lloyd 1975). At least this is true if intraindustry trade is measured at the three-digit or four-digit SITC or ISIC levels (Lipsey 1976).

Data on the dispersion of economic performance is also consistent with the prewar experience in international trade. During the early decades of the twentieth century, there was no pronounced trend in the dispersion of economic performance among the major economies, and the relative importance of international trade declined. Intraindustry trade was not growing fast enough to offset the relatively slow growth of interindustry trade (Hirschman 1945, chap. 7).

A postwar world characterized by intraindustry trade might have been expected to be relatively free of international commercial policy disputes. If the vast majority of international trade is undertaken by countries that are quite similar to each other and are primarily exchanging different varieties of similar goods produced using similar technologies, such trade is most unlikely to have the income redistribution implications associated with factorendowment-based trade. The new exchange of capital-intensive products for labor-intensive products between two countries will change the distribution of income between capital and labor in each country. Two-way trade in electrical machinery, however, is much less likely to produce this result. Perhaps this does explain why industrialized countries in the postwar world have had such great success in removing barriers among themselves and why this success has been confined to trade in manufactures. As will be seen, it may also explain the distinctively contentious relations that Japan has had with other industrialized economies.

For all the importance of intraindustry trade in the past four decades, such trade has not been an important element in Japan's postwar growth. As table

Table 6.4

Coefficient of Variation GDP per Capita of Sixteen Major Economies, 1870-1987

\begin{tabular}{ll|ll}
1870 & .279 & 1950 & .383 \\
1900 & .297 & 1973 & .171 \\
1913 & .345 & 1987 & .142 \\
1929 & .329 & & \\
\hline
\end{tabular}

Sources: Maddison (1982) and Maddison (1989).

Note: The economies in this dispersion index include Australia, Austria, Belgium, Canada, Denmark, Finland, France, Germany, ltaly, Japan, the Netherlands, Norway, Sweden, Switzerland, the United Kingdom, and the United States. 
6.5 indicates, Japan is distinctive among major industrialized countries for its very limited participation in intraindustry trade. Despite experiencing a rate of growth of foreign trade since the late 1930s that among industrialized countries is exceeded only by France and Italy, Japan's intraindustry trade has lagged.

Japan's experience has been exceptional because its postwar trade has probably grown rapidly for much the same reasons that its prewar trade also grew rapidly. Japan's continuing capacity to make use of foreign advances in science and technology and increasingly also its capacity to make efficient use of its own research and development resources has continued to make laborsaving innovations an important source of cost reduction in Japanese export industries. Where in the prewar period labor-saving innovations in export industries meant an unambiguous bias toward more trade, in postwar Japan, with labor increasingly scarce, this bias has attenuated. This may help explain why in the last decades of the twentieth century, despite a rapid stream of productivity-enhancing technological innovations, Japanese trade has not outstripped the growth of the Japanese GNP to anywhere near the extent of what was experienced in the prewar decades. Among the major industrialized economies examined here, Japan has experienced the smallest rise in its trade-toGNP ratio.

While economic theory suggests that, given Japan's distinctive geography and factor endowments, it is not surprising that Japan is a relatively meager participant in intraindustry trade, there remains a strong suspicion among Japan's trading partners that Japanese government policies are somehow responsible. ${ }^{6}$ In this event, the conjecture that Japan's meager participation in intraindustry trade might be explained by Japan's distinctive factor endowments certainly needs to be subjected to a careful empirical test.

\subsection{A Factor-Endowment-Based Theory of Intraindustry Trade ${ }^{7}$}

Assume that all manufactured goods are differentiated by country of origin. Given the same homothetic preferences usually assumed in empirical work making use of Heckscher-Ohlin-style trade models, each economy will consume identical proportions of each variety of each good. ${ }^{8}$ This means that country $j$ 's import and export of good $i$ will be given by ${ }^{9}$

$$
\begin{aligned}
M_{i j}^{+} & =S_{j}\left(\bar{Q}_{i}-Q_{i}\right) ; \\
X_{i j}^{+} & =\left(1-S_{j}\right) Q_{i j},
\end{aligned}
$$

6. Concern about Japan's meager participation in intraindustry trade dates from the late $1960 \mathrm{~s}$ (Saxonhouse 1972). Helpman and Krugman (1985) show that, the more different are two countries' factor endowments, the less the role that intraindustry trade will play in their total trade.

7. This paper extends earlier research on this subject (Saxonhouse 1989). See also the survey on earlier empirical work on Japanese trade structure in Saxonhouse and Stern (1989).

8. See, e.g., the analysis in Leamer (1984) and Saxonhouse (1983).

9. Lawrence (1987) makes use of variants of (4) and (4'). 


\begin{tabular}{lcccc}
\hline & 1975 & 1980 & 1985 & 1988 \\
\hline Japan & 26 & 28 & 26 & 33 \\
United States & 62 & 66 & 61 & 60 \\
France & 78 & 82 & 82 & 81 \\
Germany & 58 & 66 & 67 & 69 \\
Korea & 36 & 40 & 49 & N.A. \\
\hline
\end{tabular}

Sources: Iwata (1991, 333-69); and Tsushosangyōsho (1990, 208).

where $M_{i j}^{+} \equiv$ imports of good $i$ by country $j, Q_{i j} \equiv$ production of good $i$ in country $j, \bar{Q}_{i} \equiv \Sigma_{j} Q_{i j} \equiv$ global production of good $i, \Pi_{i} \equiv \Sigma Q_{i j} \equiv$ GNP of country $j, \Pi \equiv \Sigma_{j} \Pi_{j} \equiv$ global GNP and $S_{j} \equiv \Pi_{j} / \Pi \equiv$ share of country $j$ in global GNP; but

$$
S_{j}=\frac{\Pi_{j}}{\Pi}=\frac{\sum_{s} W_{s j} L_{j}}{\sum_{i} \bar{Q}_{i}}
$$

where $L_{s j}$ E endowment of factor of production $s$ in economy $j$, and $W_{s j} \equiv$ rental for factor of production $s$.

Following the approach taken in interindustry trade analyses based on the Heckscher-Ohlin framework, if factor price equalization is assumed, then, by Hotelling's lemma, if $\Pi_{j}$ is differentiated with respect to output price, ${ }^{10}$

$$
Q_{i j}=\sum_{s=1}^{N} R_{i s} L_{s j}
$$

where $R_{i s}$ is a function of the parameters of $\Pi_{j}$ and output prices, which are assumed to be constant.

Substituting (3) and (4) into (1) and (2), we get

$$
M_{i j}^{+}=\sum_{s=1}^{N} B_{i s}^{+} L_{s j}-\sum_{s=1}^{N} \sum_{r=1}^{N} D_{i s r}^{+} L_{s j} L_{r j}, \quad i=1, \ldots, N,
$$

and

$$
X_{i j}^{+}=\sum_{s=1}^{N} R_{i s} L_{s j}-\sum_{s=1}^{N} \sum_{r=1}^{N} D_{i s r}^{+} L_{s j} L_{r j}, \quad i=1, \ldots, N,
$$

where $B_{i s}^{+}$and $D_{i s r}^{+}$are functions of parameters of $\Pi_{j}$, and where output prices will be constant under the assumptions already made. The linear factorendowment terms in (5) represent economy $j$ 's demand for good $i$, while the

10. The GNP function $\Pi_{j}$ has been defined to allow for differentiated products and economies of scale. Following Helpman and Krugman (1985), this can be done by including optimal firm scale in $\Pi_{j}$. Provided that optimal firm scale is small relative to market size, change in industry output can be achieved by changes in the number of firms in the industry. Firms are assumed to be identical. This means that, at an industry level, there will be constant returns to scale. 
linear terms in (6) represent economy $j$ 's supply of good $i$. The interaction terms in equations (5) and (6) represent economy $j$ 's demand for its domestically produced variety $j$ of good $i . M_{i j}^{+}$in (5) can be interpreted as that part of economy $j$ 's demand for good $i$ that cannot be satisfied by the domestically produced variety $j . X_{i j}^{+}$in (6) is the supply of variety $j$ of good $i$ available after domestic demand has been met. Neither $M_{i j}^{+}$nor $X_{i j}^{+}$can be negative. If (5) is subtracted from (6), net exports will be given by ${ }^{11}$

$$
\left(X_{i j}^{+}-M_{i j}^{+}\right)=\sum_{s=1}^{K}\left(R_{i s}-B_{i s}^{+}\right) L_{s j}, \quad i=1, \ldots, N .
$$

Net exports reflect the balance between the domestic demand for and supply of good $i$ by economy $j$. Since domestic demand for the domestic variety of good $i$ appears in both equation (5) and equation (6), these terms cancel out in equation (7).

By contrast with (5) and (6), (7) is the traditional Heckscher-Ohlin interindustry trade equation with net exports as a linear function of factor endowments (Saxonhouse 1983; Leamer 1984). Within the Heckscher-Ohlin framework, the nonlinear terms in (5) and (6) cancel out. ${ }^{12}$

The presence of factor-endowment interaction terms in equations (5) and (6) presents a number of estimation problems. Given the desire to use a relatively homogeneous country sample, which means that only a relatively small number of observations are available, and given the large number of interaction terms, precise estimation of (5) and (6) would be difficult. Alternatively, recall from (3) and (5) that

$$
\begin{aligned}
M_{i j}^{+} & =\sum_{s=1}^{K} B_{i s}^{+} a_{s} L_{s j}-\sum_{s=1}^{K} \sum_{r=1}^{K} D_{i s r}^{+} a_{s} L_{s j} L_{r j} \\
& =\frac{\Pi_{j}}{\Pi} \bar{Q}_{i}-\frac{\Pi_{j}}{\Pi} \sum_{s=1}^{K} R_{i s} a_{s} L_{s j} .
\end{aligned}
$$

11. In the common case that the number of goods exceeds the number of factors $(N>K)$, trade will likely be indeterminate. In theory, this should mean that empirical work using such crossnational models should fare poorly (Petri 1991). In practice, such models do very well in explaining cross-national trade patterns (Leamer 1984; Saxonhouse 1983). How can this paradox be resolved? One convention might allow that in the limit there are approximately the same large number of factors as commodities and that trade patterns are determinate. Missing data present problems for estimation, but not problems for actual trade flows. If these missing factor endowments are statistically orthogonal to the factor endowments for which data are available, their absence will not bias estimation of the model. If this view is wrong, and if there are many more goods than factors of production in the international economic system, production and trade should be highly specialized. In fact, what is generally observed, at the level of disaggregation relevant for empirical work, is just the kind of incomplete specialization suggested by a system where the numbers of goods and factors are the same.

12. Since (7) can be derived from the intraindustry gross trade equations (5) and (6), this should demonstrate the compatibility of these two approaches. Contrary to what authors such as Zysman and Tyson (1983) allege, the incorporation of scale economies and product differentiation into conventional models of international trade in order to account for intraindustry trade need not invalidate the Heckscher-Ohlin interpretation of intraindustry trade. 
Dividing through by $\Pi_{j}$ we get

$$
\frac{M_{i j}^{+}}{\Pi_{j}}=\frac{\bar{Q}_{i}}{\Pi}-\frac{1}{\Pi} \sum_{s=1}^{K} R_{i s} a_{s} L_{s j}=F_{i}-\sum_{s=1}^{K} R_{i s}^{*} a_{s} L_{s j},
$$

where $F_{i} \equiv \bar{Q}_{i} / \Pi \equiv$ global sector $i$ as a proportion of global GNP and $R_{i s}^{*} \equiv R_{i s} / \Pi$.

Equation (8), like equation (7), is a simple linear function of factor endowments. When estimated together with equation (7), it can be used to test the hypothesis that the variation of intraindustry trade participation across countries is caused, not by government trade policies, but by differences in factor endowments.

The structure embodied in equations (7) and (8) results from relaxing many of the strictest assumptions of the Heckscher-Ohlin model in order to incorporate hitherto neglected phenomena. Still further relaxation of assumptions is possible. Following earlier work (Saxonhouse 1983, 1989; Bowen, Leamer, and Sveikauskas 1987), suppose that the assumption that strict factor price equalization across countries is dropped. Suppose rather that international trade equalizes factor prices only when factor prices are normalized for differences in quality. For example, observed international differences in the compensation of ostensibly unskilled labor may be accounted for by differences in labor quality. Instead of (7) and (8), we have

$$
\left(X_{i j}^{+}-M_{i j}^{+}\right)=\sum_{s=1}^{N}\left(R_{i s}-B_{i s}^{+}\right) a_{s} L_{s j}, \quad i=1, \ldots, N,
$$

and

$$
\frac{M_{i j}^{+}}{\Pi_{j}}=F_{i}-\sum_{s=1}^{K} R_{i s}^{*} a_{s} L_{s j}, \quad i=1, \ldots, N
$$

where $a_{s} \equiv$ quality of factor $s$.

\subsection{Estimation Procedures}

Equations $\left(7^{\prime}\right)$ and $\left(8^{\prime}\right)$ can be estimated for $N$ commodity groups from cross-national data. $a_{s}$ is not directly observable but can be estimated using (7) and (8) (Saxonhouse 1983, 1989). Formally, the estimation of $\left(7^{\prime}\right)$ and $\left(8^{\prime}\right)$ with $a_{s}$ differing across countries and unknown is a multiplicative errors in variables problem. Instrumental variables methods will allow consistent estimation of the $\left(R_{i s}-B_{i s}^{+}\right)$and the $R_{i s}^{*}$. For any given cross section, the $a_{s}$ will not be identified. In the particular specification adopted in $\left(7^{\prime}\right)$ and $\left(8^{\prime}\right)$, however, at any given time, there are $2 N$ cross sections that contain the identical independent variables. This circumstance can be exploited to permit consist- 
ent estimation of the $a_{s} \cdot{ }^{13}$ Since the same error will recur in equation after equation owing to the unobservable quality terms, it is possible to use this recurring error to obtain consistent estimates of the quality terms. These estimates of $a_{s}$ can then be used to adjust the factor endowment data in ( $\left.7^{\prime}\right)$ and $\left(8^{\prime}\right)$ to obtain more efficient estimates of the $\left(R_{i s}-B_{i s}^{+}\right)$and the $R_{i s}^{+}$.

\subsection{Estimating Interindustry Trade Equations and Import Share Equations}

Earlier work with a related empirical framework (Saxonhouse 1989) has been criticized because the sample used in its estimation included many poorer countries that had substantial levels of protection (Tyson 1989). The estimated coefficients of a framework such as $\left(7^{\prime}\right)$ and $\left(8^{\prime}\right)$ will embody the average level of protection of the sample used in its estimation. It is useful to know that, after due allowance has been made for its distinctive factor endowment, Japanese trade structure differs little from that of other advanced countries that are thought of as having relatively low levels of protection. It may be quite a different matter if Japanese trade structure differs little from that of mixed samples of countries, some with low levels of protection, others with extremely high levels. ${ }^{14}$ With this in mind, equations $\left(7^{\prime}\right)$ and $\left(8^{\prime}\right)$ are estimated with data taken from the relatively homogeneous sample of twenty-four economies listed in table 6.6 for 1983 for each of the sixty-one trade sectors listed in table 6.7.

The six factor endowments used in this estimation include directly productive capital stock, educational attainment, labor, petroleum reserves, coal, and arable land. Unlike the interindustry trade equation $\left(7^{\prime}\right)$, the dependent variables in the import share equation $\left(8^{\prime}\right)$ will never be negative, but they will occasionally be zero. As seen in table 6.8 , some of the import share equations will contain some zero observations. As suggested (Saxonhouse 1989), equation $\left(8^{\prime}\right)$ should be specified as a Tobit model..$^{15}$

The results of estimating equations $\left(7^{\prime}\right)$ and $\left(8^{\prime}\right)$ are given in tables 6.9 6.12. Note that thirty-eight of the sixty-one net trade equations and thirty-four of the sixty-one import share equations are statistically significant. When all 122 trade equations are taken jointly as a system, they are statistically signifi-

13. For further explanation of the statistical techniques used here, see Saxonhouse (1989).

14. In general, less advanced economies impose more protection than the most advanced economies (Honma and Hayami 1986). As noted (Saxonhouse 1989), this development-related protection can be explained by changes in the levels of the factor endowments. Typically, the less scarce the factor endowments, the less the protection. Under these conditions, using a mixed sample of advanced and developing economies will not pose much of a problem for interpreting findings about Japan because development-related protection in the sample will not be incorporated into the estimated coefficients.

15. The Tobit estimation methods used for equation $\left(8^{\prime}\right)$ are described in Greene $(1981,1983)$ and in Chung and Goldberger (1984). 
Table 6.6

Country Sample for Empirical Work

\begin{tabular}{ll}
\hline Australia & Italy \\
Austria & Japan \\
Belgium and Luxembourg & Netherlands \\
Canada & New Zealand \\
Denmark & Norway \\
Finland & Portugal \\
France & Singapore \\
Germany & Spain \\
Greece & Sweden \\
Hong Kong & Switzerland \\
Iceland & United Kingdom \\
Ireland & United States \\
\hline
\end{tabular}

Table 6.7

Trade Sectors in Sample

Petroleum, petroleum products (PETRO33)

Crude materials, crude fertilizer (MAT27)

Metalliferous ores, metal scrap (MAT28)

Coal, coke briquettes (MAT32)

Gas, natural and manufactured (MAT34)

Electrical energy (MAT35)

Nonferrous metals (MAT68)

Wood, lumber, cork (FOR24)

Pulp, waste paper (FOR25)

Wood, cork manufactures (FOR63)

Paper, paperboard (FOR64)

Fruit, vegetables (TROP5)

Sugar, sugar preparations, honey (TROP6)

Coffee, tea, cocoa, spices (TROP7)

Beverages (TROP11)

Crude rubber (TROP23)

Live animals (ANL0)

Meat, meat preparations (ANL1)

Dairy products, eggs (ANL2)

Fish, fish preparations (ANL3)

Hides, skins, furskins, undressed (ANL21)

Crude animal, vegetable minerals (ANL29)

Animal, vegetable oils, fats, processed (ANL45)

Animals, n.e.s. (ANL94)

Cereals, cereal preparations (CER4)

Tobacco, tobacco manufactures (CER12)

Oil seeds, oil nuts, oil kernels (CER22)

Textile fibers (CER26)

Animal oils, fats (CER41)

Fixed vegetable oils (CER42)

Nonmetallic mineral manufactures (LAB66)

Furniture (LAB82)

Travel goods, handbags (LAB83)

(continued) 
Table 6.7 (continued)

Clothing (LAB84)

Footwear (LAB85)

Miscellaneous manufactured articles n.e.s. (LAB89)

Postal pack not classified according to kind (LAB91)

Special transactions not classified according to kind (LAB93)

Coins, nongold, noncurrent (LAB96)

Leather, dressed furskins (CAP61)

Rubber manufactures, n.e.s. (CAP62)

Textile, yarn, fabrics (CAP65)

Iron and steel (CAP67)

Manufactures of metal (CAP69)

Sanitary fixtures, fittings (CAP81)

Machinery, other than electrical (MACH71)

Electrical machinery (MACH72)

Transport equipment (MACH73)

Professional goods, watches, instruments (MACH86)

Firearms, ammunition (MACH95)

Chemical elements, compounds (CHEM51)

Mineral tar and crude chemicals from coal, petroleum, and natural gas (CHEM52)

Dyeing, tanning, coloring matter (CHEM53)

Medicinal, pharmaceutical products (CHEM54)

Essential oils, perfume matter (CHEM55)

Fertilizers, manufactured (CHEM546)

Explosives, pyrotechnic products (CHEM57)

Plastic materials, cellulose (CHEM58)

Chemical materials, n.e.s. (CHEM59)

cant, with $F(53,2753)_{05}=3.61 .{ }^{16}$ For individual factor endowments, out of sixty-one estimated net trade equations, capital has significant coefficients in twenty-seven, labor has nineteen, education has twenty, oil has thirteen, coal has sixteen, and land has twenty. By marked contrast with the net trade results, the sixty-one import share equations have a great many more significant coefficients. What are the determinants of import shares? Capital once again has the most significant coefficients with thirty-six, labor and education have twenty-nine, oil has twenty-eight, coal has twenty-four, and arable land has thirty-four.

Consistent with earlier findings from a diverse set of economies (Saxonhouse 1989), the determinants of import shares do appear quite similar to the determinants of net trade. ${ }^{17}$ Physical capital is a source of comparative disadvantage in the net trade in natural resources and a source of comparative advantage in the net trade of capital-intensive manufactures, machinery, and

16. The joint test used here is described in McElroy (1977).

17. Lawrence (1987) suggests the contrary. 


\begin{tabular}{lc|lc}
\hline PETRO33 & 0 & CER26 & 0 \\
MAT27 & 0 & CER41 & 0 \\
MAT28 & 0 & CER42 & 0 \\
MAT32 & 0 & LAB66 & 0 \\
MAT34 & .075 & LAB82 & 0 \\
MAT35 & .525 & LAB83 & 0 \\
MAT68 & 0 & LAB84 & 0 \\
FOR24 & 0 & LAB85 & 0 \\
FOR25 & 0 & LAB91 & .125 \\
FOR63 & 0 & LAB93 & .175 \\
FOR64 & 0 & LAB96 & .025 \\
TROP5 & 0 & CAP61 & 0 \\
TROP6 & 0 & CAP62 & 0 \\
TROP7 & 0 & CAP65 & 0 \\
TROP11 & 0 & CAP67 & 0 \\
TRP23 & 0 & CAP69 & 0 \\
ANL0 & .575 & CAP81 & 0 \\
ANL1 & 0 & MACH71 & 0 \\
ANL2 & 0 & MACH72 & 0 \\
ANL3 & 0 & MACH73 & 0 \\
ANL21 & .025 & MACH95 & .075 \\
ANL29 & 0 & CHEM51 & 0 \\
ANL43 & 0 & CHEM52 & 0 \\
ANL94 & 0 & CHEM53 & 0 \\
CER4 & 0 & CHEM54 & 0 \\
CER8 & 0 & CHEM56 & 0 \\
CER9 & 0 & CHEM57 & 0 \\
CER12 & .025 & CHEM58 & 0 \\
CHER22 & 0 & CHEM59 & 0 \\
\hline
\end{tabular}

chemical products. Endowments of capital also encourage the imports of natural resource products and labor-intensive products while again discouraging the imports of capital-intensive manufactures, machinery, and chemical products.

By contrast with physical capital, labor's role as a determinant of trade patterns is more complex. Generally speaking, labor is a source of comparative advantage in the net trade of capital-intensive manufactures, labor-intensive manufactures, and chemical products. At the same time, endowments of labor also discourage the imports of most nonnatural resourcerelated manufactures. Human capital's role is also quite complicated. While human capital is a source of comparative disadvantage in net trade in natural resource-related products and a source of comparative advantage in the net trade of most nonnatural resource-related manufactures, its role as a determinant of import shares is subtle. Endowments of human capital encourage import of tropical products, animal products, labor-intensive manufactures, and 
Table 6.9 Estimation of Equation (7'):

$\left(X_{i j}^{+}-M_{i j}^{+}\right)=N_{0}+N_{1}$ Capital $+N_{2}$ Labor $+N_{3}$ Educ.

$+N_{4}$ Oil $+N_{5}$ Coal $+N_{6}$ Land Ara.

\begin{tabular}{lcc|lll}
\hline & $R_{2}$ & $F(6,17)$ & & $R^{2}$ & $F(6,17)$ \\
\hline PETRO33 & .891 & $23.2^{* *}$ & CER42 & .103 & .033 \\
MAT27 & .615 & $4.53^{* *}$ & LAB66 & .621 & $3.92^{* *}$ \\
MAT28 & .702 & $5.72^{* *}$ & LAB82 & .317 & 1.32 \\
MAT32 & .593 & $4.13^{* *}$ & LAB83 & .581 & $5.08^{* *}$ \\
MAT34 & .367 & 1.64 & LAB84 & .394 & 1.85 \\
MAT35 & .198 & .700 & LAB85 & .461 & 2.42 \\
MAT68 & .602 & $4.29 * *$ & LAB89 & .623 & $4.68^{* *}$ \\
FOR24 & .591 & $4.09^{* *}$ & LAB91 & .595 & $4.16^{* *}$ \\
FOR25 & .361 & 1.60 & LAB93 & .618 & $4.58^{* *}$ \\
FOR63 & .400 & 1.89 & LAB96 & .307 & 1.25 \\
FOR64 & .253 & .96 & CAP61 & .671 & $5.78^{* *}$ \\
TROP5 & .331 & 1.40 & CAP62 & .754 & $8.68^{* *}$ \\
TROP6 & .526 & $3.14^{* *}$ & CAP65 & .612 & $4.47^{* *}$ \\
TROP7 & .585 & $3.99^{* *}$ & CAP67 & .808 & $11.9^{* *}$ \\
TROP11 & .463 & 2.44 & CAP69 & .744 & $8.23^{* *}$ \\
TROP23 & .251 & .95 & CAP81 & .406 & 1.94 \\
ANL0 & .196 & .69 & MACH71 & .646 & $5.17^{* *}$ \\
ANL1 & .361 & 1.60 & MACH72 & .915 & $30.5^{* *}$ \\
ANL2 & .105 & .33 & MACH73 & .863 & $17.8^{* *}$ \\
ANL3 & .711 & $6.97^{* *}$ & MACH86 & .684 & $6.13^{* *}$ \\
ANL21 & .439 & 2.21 & MACH95 & .933 & $39.5^{* *}$ \\
ANL29 & .362 & 1.61 & CHEM51 & .709 & $6.90^{* *}$ \\
ANL43 & .401 & 1.90 & CHEM52 & .412 & 1.99 \\
ANL94 & .386 & 1.78 & CHEM53 & .583 & $3.96^{* *}$ \\
CER4 & .689 & $6.28^{* *}$ & CHEM54 & .526 & $3.14^{* *}$ \\
CER8 & .514 & $3.00^{* *}$ & CHEM55 & .671 & $5.78^{* *}$ \\
CER9 & .390 & 1.81 & CHEM56 & .396 & 1.86 \\
CER12 & .733 & $7.78^{* *}$ & CHEM57 & .519 & $3.06^{* *}$ \\
CER22 & .721 & $7.07^{* *}$ & CHEM58 & .591 & $3.77^{* *}$ \\
CER26 & .642 & $5.08^{* *}$ & CHEM59 & .717 & $7.18^{* *}$ \\
CER41 & .762 & $9.07^{* *}$ & & & \\
\hline & & & & & \\
\hline
\end{tabular}

${ }^{* *} F(6,17)_{05}=2.70$.

capital-intensive manufactures. At the same time, endowments of human capital strongly discourage imports of machinery and chemical products.

Surprisingly, oil and arable land appear to have quite the opposite effect from coal on trade structure. While encouraging the net export of natural resource products, factor endowments of oil and arable land are a source of comparative disadvantage for most nonnatural resource manufactures and encourage the import, in particular, of labor-intensive manufactures, capitalintensive manufactures, and chemical products. Coal's effect is much the opposite. Endowments of coal are a source of comparative advantage for net 


\begin{tabular}{|c|c|c|c|c|c|}
\hline Capital & Labor & Education & Petroleum & Coal & Land \\
\hline- & + & + & + & + & + \\
\hline
\end{tabular}

(7) Petroleum and raw materials (PETRO33, MAT27-68)

(4) Forest products (FOR24-64)

(5) Tropical products

$$
\text { (TROP5-23) }
$$

(8) Animal products (ANLO-94)

(8) Cereals (CER4-12)

(9) Labor-intensive manufactures (LAB66-96)
Capital-intensive manufactures

(6) Capital-intensive manufactures (CAP61-81)

(5) Machinery (MACH71-95)

(9) Chemical products (CHEM5159)

\begin{tabular}{|c|c|c|c|c|c|c|c|c|c|c|}
\hline a & 3 & a & 1 & a & a & 2 & a & 1 & $\mathbf{a}$ & 3 \\
\hline a & 1 & $\mathbf{a}$ & $\mathbf{a}$ & $\mathbf{a}$ & a & a & $\mathbf{a}$ & a & 1 & 1 \\
\hline a & 1 & 1 & $\mathrm{a}$ & a & 2 & $\mathbf{a}$ & 1 & $a$ & 1 & a \\
\hline a & 2 & a & 1 & a & 1 & $\mathbf{a}$ & a & 1 & a & 2 \\
\hline 2 & 2 & 2 & a & a & 3 & 2 & a & 1 & a & 1 \\
\hline 2 & 1 & 2 & $\mathbf{a}$ & 2 & 1 & $\mathbf{a}$ & 2 & $\mathbf{a}$ & 2 & a \\
\hline 4 & a & 2 & 1 & 4 & $\mathbf{a}$ & a & 3 & 1 & 1 & a \\
\hline 4 & a & 2 & 2 & 4 & a & 1 & $\mathbf{a}$ & 3 & a & $\mathrm{a}$ \\
\hline 4 & 1 & 3 & 2 & 2 & 1 & a & 2 & 4 & a & a \\
\hline
\end{tabular}

Note: Numbers in parentheses at the left of sectoral grouping rows indicate the number of equations in each sectoral grouping. a No significant coefficients in this cell. 
Table 6.11

Estimation of Equation (8'):

$$
\begin{aligned}
\frac{M_{i j}^{+}}{\Pi_{j}}= & P_{0}+P_{1} \text { Capital }+P_{2} \text { Labor }+P_{3} \text { Educ. } \\
& +P_{4} \text { Oil }+P_{5} \text { Coal }+P_{6} \text { Land Ara. }
\end{aligned}
$$

\begin{tabular}{|c|c|c|c|c|c|}
\hline & $R^{2}$ & $F(6,17)$ & & $R^{2}$ & $F(6,17)$ \\
\hline PETRO33 & .871 & $19.1^{* *}$ & CER42 & .601 & $4.27 * *$ \\
\hline MAT27 & .293 & 1.17 & LAB66 & .578 & $3.88 * *$ \\
\hline MAT28 & .116 & .13 & LAB82 & .409 & 1.96 \\
\hline MAT32 & .068 & .21 & LAB83 & .663 & $5.57 * *$ \\
\hline MAT34 & .071 & .22 & LAB84 & .436 & 2.19 \\
\hline MAT35 & .096 & .30 & LAB85 & .399 & 1.88 \\
\hline MAT68 & .507 & $2.91^{* *}$ & LAB89 & .676 & $5.91 * *$ \\
\hline FOR24 & .414 & 2.00 & LAB91 & .173 & .59 \\
\hline FOR25 & .394 & 1.84 & LAB93 & .451 & 2.33 \\
\hline FOR63 & .173 & .59 & LAB96 & .432 & 2.15 \\
\hline FOR64 & .512 & $2.97 * *$ & CAP61 & .671 & $5.78^{* *}$ \\
\hline TROP5 & .594 & $4.15^{* *}$ & CAP62 & .754 & $8.68 * *$ \\
\hline TROP6 & .390 & 1.81 & CAP65 & .635 & $4.93 * *$ \\
\hline TROP7 & .619 & $4.60 * *$ & CAP67 & .764 & $9.17^{* *}$ \\
\hline TROP11 & .563 & $3.65^{* *}$ & CAP69 & .631 & $6.65^{* *}$ \\
\hline TROP23 & .714 & $7.07 * *$ & CAP81 & .611 & $5.99^{* * *}$ \\
\hline ANLO & .430 & 2.14 & $\mathrm{MACH} 71$ & .698 & $6.55^{* * *}$ \\
\hline ANLl & .526 & $3.14^{* *}$ & $\mathrm{MACH} 72$ & .861 & $17.6^{* *}$ \\
\hline ANL2 & .511 & $2.96^{* *}$ & MACH73 & .903 & $26.4^{* *}$ \\
\hline ANL3 & .922 & $33.5^{* *}$ & $\mathrm{MACH} 86$ & .869 & $17.7^{* *}$ \\
\hline ANL21 & .095 & .30 & MACH95 & .090 & .28 \\
\hline ANL29 & .537 & $3.29 * *$ & CHEM5I & .453 & 2.35 \\
\hline ANL43 & .845 & $15.4 * *$ & CHEM52 & .314 & 1.30 \\
\hline ANL94 & .573 & $3.80^{* * *}$ & CHEM53 & .672 & $5.80^{* * *}$ \\
\hline CER4 & .362 & 1.61 & CHEM54 & .539 & $3.31 * *$ \\
\hline CER8 & .411 & 1.98 & CHEM55 & .663 & $5.57 * *$ \\
\hline CER9 & .551 & $3.48 * *$ & CHEM56 & .081 & .25 \\
\hline CER 12 & .372 & 1.68 & CHEM57 & .703 & $6.71 * *$ \\
\hline CER22 & .177 & .61 & CHEM58 & .426 & 2.10 \\
\hline CER26 & .540 & $3.33^{* *}$ & CHEM59 & .598 & $4.21^{* *}$ \\
\hline CER41 & .136 & .45 & & & \\
\hline
\end{tabular}

$* *$ Significant at the .05 level, $F(6,17)_{.05}=2.70$.

trade in capital-intensive manufactures, machinery, and chemical products. Coal endowments also discourage the imports of most nonnatural resource manufactures in addition to discouraging the imports of oil. ${ }^{18}$

18. Despite a sample restricted to relatively high-income countries, the findings presented here are quite similar to the results obtained when a more comprehensive sample of countries is used (Saxonhouse 1989). 


\begin{tabular}{|c|c|c|c|c|c|c|c|c|c|c|c|c|c|}
\hline \multirow[t]{3}{*}{ Tahle 6.12} & of : & & & ent & & & $\mathbf{S}$ & & & tor & & $t$, & \\
\hline & \multirow[b]{2}{*}{$F_{i}$} & \multicolumn{2}{|c|}{ Capital } & \multicolumn{2}{|c|}{ Labor } & \multicolumn{2}{|c|}{ Education } & \multicolumn{2}{|c|}{ Petroleum } & \multicolumn{2}{|c|}{ Coal } & \multicolumn{2}{|c|}{ Land } \\
\hline & & + & - & + & - & + & - & + & - & + & - & + & - \\
\hline $\begin{array}{l}\text { (7) Petroleum and raw } \\
\text { materials (PETRO33, } \\
\text { MAT27-68) }\end{array}$ & 3 & 1 & 1 & 1 & 1 & a & 1 & a & 2 & a & 1 & a & 3 \\
\hline $\begin{array}{l}\text { (4) Forest products } \\
\text { (FOR24-64) }\end{array}$ & 2 & 1 & a & 2 & 1 & a & 1 & a & 2 & a & a & 2 & a \\
\hline $\begin{array}{l}\text { (5) Tropical products } \\
\text { (TROP5-23) }\end{array}$ & 4 & 2 & 1 & 1 & 2 & 2 & 1 & 2 & 1 & $a$ & a & 1 & 2 \\
\hline $\begin{array}{l}\text { (8) Animal products } \\
\text { (ANL0-94) }\end{array}$ & 5 & 3 & 1 & 1 & 2 & 2 & 1 & 3 & 1 & 3 & 2 & 1 & 3 \\
\hline (8) Cereals (CER4-12) & 6 & 3 & 2 & 2 & 2 & 2 & 2 & 1 & 2 & 1 & 1 & * & 5 \\
\hline $\begin{array}{l}\text { (9) Labor-intensive man- } \\
\text { ufactures (LAB66-96) }\end{array}$ & 6 & 3 & 2 & a & 4 & 2 & 1 & 2 & 2 & 2 & 2 & 1 & 3 \\
\hline $\begin{array}{l}\text { (6) Capital-intensive } \\
\text { manufactures (CAP61- } \\
81 \text { ) }\end{array}$ & 5 & 1 & 3 & 1 & 2 & 3 & 1 & 2 & 2 & 1 & 3 & 4 & 1 \\
\hline $\begin{array}{l}\text { (5) Machinery } \\
\text { (MACH71-95) }\end{array}$ & 4 & 1 & 3 & 1 & 3 & 1 & 4 & 1 & 1 & $\mathbf{a}$ & 4 & 2 & 2 \\
\hline $\begin{array}{l}\text { (9) Chemical products } \\
\text { (CHEM51-59) }\end{array}$ & 7 & 2 & 6 & 1 & 4 & 1 & 4 & 3 & 1 & $\mathbf{a}$ & 4 & 3 & 1 \\
\hline
\end{tabular}

Note: Numbers in parentheses at the left of sectoral grouping rows indicate the number of equations in each sectoral grouping. ${ }^{a}$ No significant coefficients in this cell. 


\subsection{Is Japanese Trade Behavior Distinctive?}

Tables 6.9-6.12 report results where equations $\left(7^{\prime}\right)$ and $\left(8^{\prime}\right)$ have been estimated using 1983 data but without using Japanese observations. Equations $\left(7^{\prime}\right)$ and $\left(8^{\prime}\right)$ have also been reestimated including Japan but successively excluding Canada, the United States, and Singapore from the sample. In an effort to test whether Japanese trade patterns are distinctively different from the patterns observed by other countries, and following suggestions from Srinavasan and Hamada (1989), tolerance intervals have been constructed for Japanese trade flows using the trade equations that were estimated without Japanese observations. Unlike forecast intervals (Saxonhouse 1989), which focus on particular parameters, tolerance intervals, by indicating the probability with which a given proportion of a population distribution will fall within a particular range, provide a conceptually sound test of whether Japanese trade patterns are distinctively different from the patterns observed by other countries. ${ }^{19}$ Observations on Japanese import shares and Japanese net trade that lie outside the tolerance interval can be considered out of line with what might be expected given the experience of other countries.

To the extent that tolerance intervals constructed with non-Japanese evidence can capture Japan's trade structure, it is difficult to argue that Japan's sectoral policies are yielding distinctive outcomes. It is very important to note here that this does not necessarily mean that Japan has a liberal trade regime. If all countries with relatively small amounts of arable land protect their wheat growers, Japan can protect its wheat growers, but its behavior will not appear distinctive. At the same time, a change in Japanese trade policy will yield an increase in Japanese wheat imports. It is also important to note that, even if observations on Japanese import shares and Japanese net trade lie outside the tolerance interval, this result need not be attributed to the presence of Japanese trade barriers. There may be other important variables, for example, foreign trade barriers that have also been excluded from the model being employed here.

The tolerance interval results are presented in tables 6.13-6.16. Of the 122 actual observations on Japanese net trade and Japanese import shares, only seventeen lie outside the constructed tolerance intervals. This is virtually identical to the finding for Canadian net trade and import shares. By contrast, ten observations on U.S. net trade and import shares and no less than twentythree observations on Singaporean net trade and import shares lie outside the tolerance intervals. These findings appear broadly consistent with earlier re-

19. Saxonhouse (1989) uses forecast intervals to test whether Japanese trade patterns are distinctive. For any given probability, forecast intervals will almost always be narrower than tolerance intervals. Using forecast intervals instead of tolerance intervals biases any test in favor of accepting the hypothesis that Japanese performance is distinctive. To the extent that this hypothesis is largely rejected when forecast intervals are used, it will also be rejected when tolerance intervals are used (Christ 1966). 
Table 6.13

Extreme Observations on Net Trade, 1983

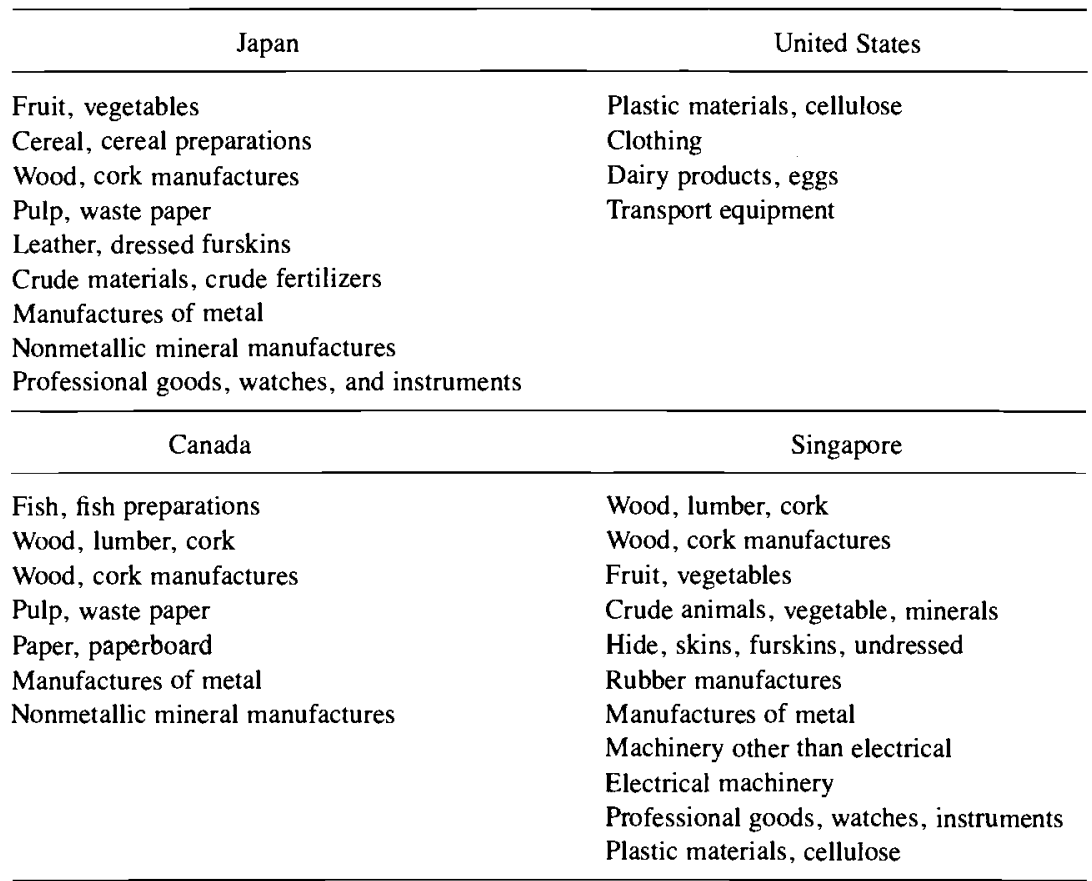

Table 6.14

Does $\left(X_{i j}^{+}-M_{i j}^{+}\right)$Lie Outside the Estimated Tolerance Interval? Test Statistic for Case where 95 Percent of Population Distribution Is Included in Tolerance Interval with Probability .95

\begin{tabular}{lcccc}
\hline & Japan & U.S & Canada & Singapore \\
\hline PETRO33 & .75 & 2.32 & 1.05 & .82 \\
MAT27 & $3.78^{*}$ & .92 & 1.88 & 1.67 \\
MAT28 & 2.15 & 2.88 & 1.72 & 1.61 \\
MAT32 & 1.91 & 3.03 & 2.14 & 2.61 \\
MAT34 & 1.45 & 1.22 & 1.52 & 1.38 \\
MAT35 & 1.16 & 2.36 & 2.45 & 1.99 \\
MAT68 & 2.12 & 1.52 & 2.10 & .92 \\
FOR24 & 2.70 & 2.35 & $3.88^{*}$ & $4.01^{*}$ \\
FOR25 & $3.72^{*}$ & 1.97 & 1.54 & 2.79 \\
FOR63 & $21.58^{*}$ & 2.62 & $4.41^{*}$ & $4.67^{*}$ \\
FOR64 & 3.25 & 1.74 & $3.85^{*}$ & 3.24 \\
TROP5 & $4.68^{*}$ & .41 & 2.44 & $3.86^{*}$ \\
TROP6 & .62 & 1.81 & .92 & 2.07 \\
TROP7 & 1.14 & 1.92 & 2.63 & 1.68 \\
TROP11 & .83 & .77 & 1.56 & .92 \\
TROP23 & .41 & 1.76 & 2.04 & 2.33 \\
ANL0 & .36 & .62 & .92 & 1.36 \\
ANL1 & 2.87 & 1.63 & 1.76 & 1.14 \\
(continued) & & & &
\end{tabular}


Table 6.14 (continued)

\begin{tabular}{|c|c|c|c|c|}
\hline & Japan & U.S. & Canada & Singapore \\
\hline ANL2 & 3.06 & $3.69^{*}$ & 2.14 & 1.17 \\
\hline ANL3 & 2.88 & .87 & $4.15^{*}$ & 2.14 \\
\hline ANL21 & 3.21 & 1.51 & 2.11 & $6.12^{*}$ \\
\hline ANL29 & 1.42 & .12 & .78 & $4.06^{*}$ \\
\hline ANL45 & .33 & 1.26 & 1.98 & .54 \\
\hline ANL94 & .93 & 1.58 & 1.03 & 1.36 \\
\hline CER4 & $4.62^{*}$ & $3.67^{*}$ & 1.40 & 1.64 \\
\hline CER8 & 2.15 & 2.26 & 1.52 & .38 \\
\hline CER9 & 2.76 & 1.21 & .75 & 1.63 \\
\hline CER 12 & 3.20 & .93 & 1.58 & .19 \\
\hline CER22 & .84 & .67 & 3.14 & 2.78 \\
\hline CER26 & 1.34 & .42 & 3.11 & 3.36 \\
\hline CER41 & .82 & .63 & 1.57 & 1.01 \\
\hline CER42 & 1.13 & 1.67 & 1.42 & 1.22 \\
\hline LAB66 & $3.78^{*}$ & 3.26 & $3.68^{*}$ & 2.94 \\
\hline LAB82 & 2.56 & 2.89 & 2.44 & 2.62 \\
\hline LAB83 & 1.31 & 2.29 & 1.94 & 2.35 \\
\hline LAB84 & 2.50 & $4.33^{*}$ & 1.73 & 3.32 \\
\hline LAB85 & 3.21 & 2.84 & 2.27 & 2.86 \\
\hline LAB89 & 1.78 & 1.63 & .67 & 1.55 \\
\hline LAB91 & .62 & .73 & .95 & 1.24 \\
\hline LAB93 & .45 & .85 & 1.36 & 1.55 \\
\hline LAB96 & .41 & .53 & 1.28 & .89 \\
\hline CAP61 & $3.71 *$ & 1.48 & 3.00 & 1.46 \\
\hline CAP62 & .97 & .58 & 3.34 & $3.92^{*}$ \\
\hline CAP65 & .70 & 3.19 & 1.09 & 1.85 \\
\hline CAP67 & 1.72 & 1.88 & 2.51 & 2.63 \\
\hline CAP69 & $4.32 *$ & 3.15 & $3.98 *$ & $4.66^{*}$ \\
\hline CAP81 & .44 & 1.23 & .99 & 1.54 \\
\hline MACH71 & 1.19 & 1.07 & 2.54 & $5.93 *$ \\
\hline $\mathrm{MACH} 72$ & 1.36 & .68 & 3.50 & 3.39 \\
\hline MACH73 & 3.15 & 4.02 & 3.26 & 3.20 \\
\hline MACH86 & $3.89 *$ & 1.74 & 1.45 & $5.43^{*}$ \\
\hline МACH95 & .57 & .82 & 1.76 & 1.63 \\
\hline CHEM51 & .60 & 1.98 & 1.17 & .88 \\
\hline CHEM52 & 1.31 & .85 & 1.94 & 1.56 \\
\hline CHEM53 & .33 & 1.52 & 1.00 & 1.43 \\
\hline CHEM54 & .59 & .26 & .75 & 1.62 \\
\hline CHEM55 & 1.16 & 1.03 & 1.35 & 1.27 \\
\hline CHEM56 & .76 & 2.35 & 1.87 & 2.04 \\
\hline CHEM57 & .54 & 1.19 & 2.16 & .70 \\
\hline CHEM58 & .96 & $5.12^{*}$ & 1.30 & $4.53^{*}$ \\
\hline CHEM59 & 1.16 & 2.28 & .43 & 3.16 \\
\hline
\end{tabular}

* = observation lies outside tolerance interval. 
Extreme Observations on Import Shares, 1979

\begin{tabular}{|c|c|}
\hline Japan & United States \\
\hline Wood, cork manufactures & Metalliferous ore, metal scrap \\
\hline Meat, meat preparations & Clothing \\
\hline Cereal, cereal preparations & Footwear \\
\hline Feedstuff for animals & Textile yarn, fabrics \\
\hline Tobacco, tobacco manufactures & Rubber manufactures \\
\hline Footwear & Transport equipment \\
\hline \multicolumn{2}{|l|}{$\begin{array}{l}\text { Rubber manufactures, n.e.s. } \\
\text { Textiles, yarn, fabrics }\end{array}$} \\
\hline Canada & Singapore \\
\hline Wood, lumber, cork & Coal, coke briquettes \\
\hline Paper, paperboard & Wood, cork manufactures \\
\hline Oil seeds, oil nuts and nut kernels & Fruit, vegetables \\
\hline Leather dressed furskins & Sugar, sugar preparations \\
\hline Rubber manufactures & Cereal, cereal preparations \\
\hline Manufactures of metal & Oil seeds, oil nuts, oil kernels \\
\hline \multirow[t]{8}{*}{ Machinery, other than electrical } & Textile fibers \\
\hline & Crude animals, vegetables and minerals \\
\hline & Leather, dressed furskins \\
\hline & Rubber manufactures \\
\hline & Machinery other than electrical \\
\hline & Transport equipment \\
\hline & Medicinal pharmaceutical products \\
\hline & Plastic materials, cellulose \\
\hline
\end{tabular}

Table 6.16

Does $\boldsymbol{M}_{i j}^{*} / \Pi_{j}$ Lie Outside the Estimated Tolerance Interval? Test Statistic for Case Where 95 Percent of Population Distribution Is Included in Tolerance Interval with Probability .95

\begin{tabular}{lcccc}
\hline & Japan & U.S. & Canada & Singapore \\
\hline PETRO33 & .83 & 1.79 & .76 & 1.32 \\
MAT27 & .74 & 2.31 & 2.07 & 1.44 \\
MAT32 & 1.55 & 3.10 & 1.04 & $4.77^{*}$ \\
MAT28 & 1.26 & $4.14^{*}$ & .76 & 2.62 \\
MAT34 & 1.21 & 1.36 & 2.52 & 3.16 \\
MAT35 & .66 & 2.12 & 2.80 & 1.95 \\
MAT68 & 2.15 & 1.47 & 3.13 & 1.73 \\
FOR24 & 3.01 & 2.68 & $3.90^{*}$ & 2.89 \\
FOR25 & 1.92 & .63 & 1.71 & 2.14 \\
FOR63 & $4.36 *$ & 2.94 & 3.39 & $3.72^{*}$ \\
FOR64 & 2.83 & 2.51 & $4.04^{*}$ & 2.11 \\
TROP5 & 3.17 & .62 & 1.86 & $4.23^{*}$ \\
TROP6 & 1.62 & 2.24 & .73 & $3.91^{*}$ \\
TROP7 & .82 & 1.47 & 1.65 & 1.80 \\
TROP11 & .51 & 2.76 & 1.32 & .92 \\
TROP23 & .73 & 1.05 & .97 & 1.58 \\
(con11ned) & & & &
\end{tabular}

(continued) 
Table 6.16 (continued)

\begin{tabular}{|c|c|c|c|c|}
\hline & Japan & U.S. & Canada & Singapore \\
\hline ANLO & .17 & 1.62 & 1.34 & 1.76 \\
\hline ANLl & $5.14^{*}$ & 2.49 & .93 & 2.14 \\
\hline ANL2 & 2.86 & 1.77 & 2.13 & .91 \\
\hline ANL3 & 2.65 & .82 & .34 & 1.53 \\
\hline ANL21 & 1.07 & 1.38 & 2.40 & .69 \\
\hline ANL29 & .94 & 1.26 & 1.73 & 3.01 \\
\hline ANL45 & 1.17 & 1.94 & 1.68 & 2.15 \\
\hline ANL94 & .42 & 1.23 & .28 & 1.37 \\
\hline CER4 & $6.38^{*}$ & 2.60 & 2.15 & $4.76^{*}$ \\
\hline CER 8 & $3.66^{*}$ & 2.82 & 3.21 & 3.25 \\
\hline CER9 & 2.26 & .89 & 1.43 & 1.87 \\
\hline CER 12 & $4.10^{*}$ & 1.04 & 1.26 & .92 \\
\hline CER22 & .88 & .71 & $3.91^{*}$ & $4.43^{*}$ \\
\hline CER26 & 1.83 & 2.47 & 1.60 & $5.00^{*}$ \\
\hline CER41 & .65 & .98 & 2.26 & 1.93 \\
\hline CER42 & .78 & 1.19 & 2.68 & 1.55 \\
\hline LAB66 & 2.09 & 1.86 & 1.13 & 2.14 \\
\hline LAB82 & 1.38 & 1.22 & 2.39 & 1.52 \\
\hline LAB83 & .92 & .57 & 1.84 & 1.99 \\
\hline LAB84 & 2.84 & $4.15^{*}$ & 1.92 & 2.35 \\
\hline LAB85 & $4.32 *$ & $3.69 *$ & 2.34 & 1.92 \\
\hline LAB89 & 1.51 & .72 & .97 & 1.36 \\
\hline LAB9 I & .79 & .42 & .93 & .62 \\
\hline LAB93 & .45 & .39 & .62 & 1.14 \\
\hline LAB96 & .76 & .41 & .53 & .96 \\
\hline CAP61 & 1.63 & 2.15 & $4.54^{*}$ & $5.32^{*}$ \\
\hline CAP62 & $3.67^{*}$ & $4.79 *$ & $5.27^{*}$ & $6.03^{*}$ \\
\hline CAP65 & $4.38^{*}$ & $4.87^{*}$ & 3.24 & 3.41 \\
\hline CAP67 & 1.36 & .74 & 3.13 & 2.37 \\
\hline CAP69 & 1.53 & 1.32 & $4.12^{*}$ & 2.80 \\
\hline CAP81 & .37 & 1.98 & 1.44 & 1.26 \\
\hline $\mathrm{MACH} 7 \mathrm{I}$ & 3.07 & 3.14 & $3.82^{*}$ & $6.35^{*}$ \\
\hline $\mathrm{MACH} 72$ & 2.17 & 1.31 & 1.04 & 2.96 \\
\hline $\mathrm{MACH} 73$ & .94 & $3.64^{*}$ & 1.77 & $6.82 *$ \\
\hline MACH86 & 1.26 & 1.06 & 2.58 & 3.27 \\
\hline MACH95 & 2.15 & 1.68 & .85 & 2.00 \\
\hline CHEM5l & 1.76 & .88 & .73 & 1.21 \\
\hline CHEM52 & .33 & .76 & 1.52 & 1.93 \\
\hline CHEM53 & .65 & .84 & 1.25 & 2.62 \\
\hline CHEM54 & 1.15 & 1.62 & .29 & $3.67^{*}$ \\
\hline CHEM55 & 1.09 & .90 & .76 & .94 \\
\hline CHEM56 & 1.84 & 1.35 & .92 & .67 \\
\hline CHEM57 & 1.55 & .58 & 2.67 & 1.53 \\
\hline CHEM58 & 2.14 & 2.86 & 3.42 & $5.38 *$ \\
\hline CHEM59 & .75 & 1.11 & .92 & 2.74 \\
\hline
\end{tabular}

$* \equiv$ observation lies outside tolerance interval. 
search that used more a heterogeneous sample of countries (Saxonhouse 1989). Whatever Japanese trade policies (and/or informal barriers) may have been, more than likely, with the possible exception of a number of agricultural sectors, they have not been a major determinant of what is distinctive about Japanese trade patterns.

Following a suggestion by Bowen (1989), the significance of this finding can be further explored by using estimated equations $\left(7^{\prime}\right)$ and $\left(8^{\prime}\right)$ to replicate intraindustry trade indices similar to those presented in table 6.5 By successively reestimating equations $\left(7^{\prime}\right)$ and $\left(8^{\prime}\right)$ and a related GNP equation, each time excluding a different country, not just Japan, Canada, the United States, and Singapore, but also each of ten other countries, it is possible to examine how the factor-endowment-based explanation of net trade and import shares can also account for intercountry variations in intraindustry trade. The results of replicating intraindustry trade indices for 1979 and 1986 using export and import values that have been forecast from equations $\left(7^{\prime}\right)$ and $\left(8^{\prime}\right)$ and the associated GNP function are presented in table 6.17.

While it could hardly be expected that intraindustry trade indices using forecasted trade flows would exactly match the indices constructed using actual data, as seen in table 6.17 the general patterns of cross-national participation in intraindustry trade in both 1979 and 1988 are clearly captured. Countries such as Canada, France, the Netherlands, and the United Kingdom that are very active participants in intraindustry trade are forecast as active

Table 6.17

Intraindustry Manufacturing Trade Indices, 1979 and 1988 (36 sectors)

\begin{tabular}{lccccc}
\hline \multirow{2}{*}{ Country } & \multicolumn{2}{c}{1979} & & \multicolumn{2}{c}{1988} \\
\cline { 2 - 3 } \cline { 5 - 6 } & Actual & Forecast & & Actual & Forecast \\
\hline Australia & .38 & .43 & & .40 & .42 \\
Belgium and Luxembourg & .85 & .69 & & .88 & .75 \\
Canada & .74 & .66 & & .78 & .73 \\
Finland & .59 & .60 & & .62 & .58 \\
France & .79 & .73 & & .83 & .75 \\
Germany & .68 & .64 & & .69 & .64 \\
Italy & .60 & .61 & & .64 & .67 \\
Japan & .35 & .32 & .39 & .37 \\
Netherlands & .71 & .83 & & .73 & .85 \\
Norway & .57 & .61 & & .63 & .62 \\
Sweden & .73 & .59 & .70 & .56 \\
United Kingdom & .82 & .80 & .84 & .84 \\
United States & .65 & .58 & .69 & .63 \\
Singapore & .48 & .42 & .58 & .54 \\
Switzerland & .67 & .71 & .64 & .75 \\
\hline
\end{tabular}

Note: Index $j=\sum_{n=1}^{n}\left[\left(X_{i j}+M_{i j}\right)-\mid X_{i j}-M_{i j}\right] \mid \sum_{i=1}^{n}\left(X_{i j}+M_{i j}\right)$. 
participants. The behavior of countries such as Australia, Singapore, and Japan that have been much less active participants in such trade are also accurately forecast. The substantial changes in the participation in intraindustry trade for many countries between 1979 and 1988 are also accurately forecast. The results for Japan are particularly instructive. Consistent with the new theory of intraindustry trade, they demonstrate that Japan is a relatively meager participant because, with its very distinctive pattern of factor endowments, it does remain quite unlike its trading partners. As shown in table 6.17, in the late 1980s Japan's participation in intraindustry trade has been increasing. This primarily reflects the increasing capital intensity and skill intensity of many of Japan's substantial trading partners in East and Southeast Asia.

\subsection{Finale}

Regardless of its determinants, Japan's distinctive pattern of trade has posed a continuing dilemma for Japanese international economic policy. There have always been important political constituencies in the major industrialized nations supporting trade in otherwise unavailable natural resource products. There has also been great support in the postwar period for the highly beneficial and minimally disruptive trade based on intraindustry specialization. A large proportion of the total volume of post-World War II trade has been of these two types. Together, constituencies supporting these two types of trade have successively pushed the almost unprecedented liberalization of the postwar international commercial system. ${ }^{20}$

Japan is neither a natural resource products-based exporter nor a major participant in intraindustry trade. Japan's focus on interindustry specialization has meant that, at the best case, expansion of Japanese trade improves foreign welfare on net while altering the almost always politically sensitive foreign income distribution. At worst, an expansion of Japanese trade can reduce foreign welfare by undermining the economic rents embodied in the profits and in the high wages of foreign industries producing tradable goods (Krugman 1984; Katz and Summers 1989). While there is very good reason to believe that, on net, the growth in Japanese trade has been beneficial, to date Japanese trade has not created powerful liberal trade constituencies within its trading partners. Rather, the faster-than-desired structural adjustment imposed on its trading partners has nurtured protectionist interests. As long as the Japanese economy was relatively small, complaints were localized, confined to particular sectors and, at the general level, relatively easily overwhelmed by the constituencies favoring more liberal trade. As Japan has become a much larger force in the global economy, and with its influence magnified by needless mismanagement of the American economy, attention has come to focus on

20. The remarkably prescient discussion in Hansen (1945) is very instructive on this point. 
the disruptive features of international trade at the expense of trade's many benefits.

As discussed earlier, mutual beneficial interindustry trade is based on the existence of differences among countries. By contrast, mutually beneficial intraindustry trade is based on similarities among countries. From the traditional Japanese perspective, it is doubtless puzzling that foreign diplomats continually request that Japan become ever more like its trading partners. It is often argued that removing what is distinctive about Japan might diminish the basis for trade. Ironically, foreign diplomats, however, are approaching Japan from a different perspective. By asking Japan to harmonize a wide array of its domestic economic practices with foreign practices, they are hoping to create a basis for greatly expanded, mutually beneficial intraindustry trade between Japan and its trading partners. If harmonization by itself helps to shore up the tattered legitimacy of the international trading system, then the hard diplomacy required to achieve this end may well be worth the great effort that has been expended. If, however, the only criteria for success are major changes in trade structure and trade volume, the research presented here continues to support the position that increased frustration and ill will may be the only outcome of such efforts. Japan will become a major participant in intraindustry trade only as the rest of natural resource-poor East and Southeast Asia converge to the Japanese level of development.

\section{References}

Baumol, William, Sue Anne Blackman, and Edward Wolff. 1989. Productivity and American leadership. Cambridge, Mass.: MIT Press.

Bhagwati, Jagdish. 1964. A survey of the pure theory of international trade. Economic Journal 74 (March): 1-84.

Bowen, Harry P. 1989. Comment. In Trade policies for international competitiveness, ed. Robert Feenstra. Chicago: University of Chicago Press.

Bowen, Harry P., Edward E. Leamer, and Leo Sveikauskas. 1987. Multicountry, multifactor tests of the factor abundance theory. American Economic Review 77 (September): 791-809.

Christ, Carl F. 1966. Econometric models and methods. New York: Wiley.

Chung, Ching-Fan, and Arthur S. Goldberger. 1984. Proportional projections in limited dependent variables models. Econometrica 52 (March): 53I-34.

Cooper, Richard N. 1964. Foreign trade and economic growth. Journal of Economic History 23 (December): 609-28.

Crafts, N. F. R., and Mark Thomas. 1986. Comparative advantage in UK manufacturing trade. Economic Journal 96 (September): 629-45.

De Long, J. Bradford. 1988. Productivity growth, convergence and welfare: Comment. American Economic Review 78 (December): 1138-54.

Dore, Ronald. 1965. Tokugawa education. Berkeley: University of California Press.

Freeman, Richard B., and Martin Weitzman. 1987. Bonuses and employment in postwar Japan. Journal of the Japanese and International Economies 2:168-94. 
Greene, William H. 1981. On the asymptotic bias of the ordinary least squares estimator of the Tobit model. Econometrica 49 (March): 505-14.

1983. Estimation of limited dependent variable models by ordinary least squares and the method of moments. Journal of Econometrics 21 (February): 195212.

Grubel, Herbert C., and P. J. Lloyd. 1975. Intra-industry trade. New York: Wiley.

Hansen, Alvin H. 1945. America's role in the world economy. New York: Norton.

Helpman, Elhanan. 1987. Imperfect competition and international trade: Evidence from fourteen industrial countries. Journal of the Japanese and International Economies 1 (March): 62-81.

Helpman, Elhanan, and Paul Krugman. 1985. Market structure and foreign trade. Cambridge, Mass.: MIT Press.

Hirschman, Albert O. 1945. National power and the structure of foreign trade. Berkeley: University of California Press.

Honma, Masayoshi, and Yujiro Hayami. 1986. Structure of agricultural protection in developed countries. Journal of International Economics 20 (February): 115-31.

Iwata, Kazumasa. 1991. Japan's intra-industry trade and intra-firm trade in the 1980's. In The Asia Pacific region in the 1990's, ed. Yoshida Taroichi. Tokyo: Foundation for Advanced Information and Research.

Katz, Lawrence, and Lawrence Summers. 1989. Can interindustry wage differentials justify strategic trade policy. In Trade policies for international competitiveness, ed. Robert Feenstra. Chicago: University of Chicago Press.

Keynes, John M. 1933. National self sufficiency. Yale Review 22 (June): 755-69.

Krugman, Paul R. 1984. The U.S. response to foreign industrial targeting. Brookings Papers on Economic Activity, no. 1:77-121.

Lawrence, Robert A. 1987. Does Japan import too little: Closed minds or markets? Brookings Papers on Economic Activity, no. 2:517-54.

Leamer, Edward E. 1984. Sources of international comparative advantage. Cambridge, Mass.: MIT Press.

Lipsey, Robert E. 1976. Review of Grubel and Lloyd. Journal of International Economics 6 (November): 312-14.

McElroy, M. B. 1977. Goodness of fit for seemingly unrelated regressions. Journal of Econometrics 6 (November): 381-87.

Maddison, Angus. 1982. Phases of capitalist development. Oxford: Oxford University Press.

1989. The world economy in the 20th century. Paris: OECD.

Ohkawa, Kazushi. 1978. Initial conditions: Economic level and structure. In Japan's historical development experience and the contemporary developing countries: Issues for comparative analysis, ed. Kazushi Ohkawa and Yujiro Hayami. Tokyo: International Development Center of Japan.

Ohkawa, Kazushi, and Henry Rosovsky. 1973. Japanese economic growth. Stanford, Calif.: Stanford University Press.

Petri, Peter. 1991. Market structure, comparative advantage, and Japanese trade under the strong yen. In Trade with Japan, ed. Paul Krugman. Chicago: University of Chicago Press.

Robertson, Dennis. 1938. The future of international trade. Economic Journal 48:1-14.

Saxonhouse, Gary R. 1972. Employment, imports, yen and the dollar. In Discord in the Pacific, ed. Henry Rosovsky. Washington, D.C.: Columbia.

- 1976. Country girls and communication among competitors in the Japanese cotton spinning industry. In Japanese industrialization and its social consequences, ed. Hugh Patrick. Berkeley: University of California Press. 
1983. The micro- and macroeconomics of foreign sales to Japan. In Trade policy for 1980's, ed. William R. Cline. Cambridge, Mass.: MIT Press.

1989. Differentiated products, economies of scale, and access to the Japanese market. In Trade policies of international competitiveness, ed. Robert Feenstra. Chicago: University of Chicago Press.

1991. Japan, SII and the international harmonization of domestic economic practices. Michigan Journal of International Law 12 (Winter): 450-69.

Saxonhouse, Gary, and Gustav Ranis. 1985. Technology and the quality dimension in Japanese cotton textile industry. In Japan and the developing economies, ed. Kazushi Ohkawa and Gustav Ranis. Oxford: Basil Blackwell.

Saxonhouse, Gary, and Robert M. Stern. 1989. An analytical survey of formal and informal barriers to international trade and investment in the United States, Canada, and Japan. In Trade and investment relations among the United States, Canada, and Japan, ed. Robert M. Stern. Chicago: University of Chicago Press.

Sombart, Werner. 1903. Die deutsche Volkswirtschaft in neunzehnten Jahrhundert und Anfang des 20. Jahrhunderts. Berlin: G. Bondi.

Srinavasan, T. N., and Koichi Hamada. 1989. The United States-Japan problem. Yale University. Typescript.

Torrens, Robert. [1821] 1965. Essay on the production of wealth. Reprint . New York: A. M. Kelley.

Tsushosangyōsho. 1990. Tsushōhakushō heisei ni-nen. Tokyo.

Tyson, Laura. 1989. Comment. In Trade policies for international competitiveness, ed. Robert Feenstra. Chicago: University of Chicago Press.

Umemura, Mataji. 1973. A note on economic development in the Tokugawa period. In The Japanese experience since the Meiji period, ed. Kazushi Ohkawa and Yujiro Hayami. Tokyo: Japan Economic Research Center.

Weitzman, Martin. 1984. The share economy. Cambridge, Mass.: Harvard University Press.

Williamson, Jeffrey G. 1991. Productivity and American leadership: A review essay. Journal of Economic Literature 29 (March): 59-68.

World Bank. 1986. World bank tables. Washington, D.C.

Wright, Gavin. 1990. American industrial leadership success, 1879-1940. American Economic Review 80 (September): 651-68.

Yamazawa, Ippei. 1978. Industrialization and external relations: Comparative analyses of Japan's historical experience and contemporary developing countries' performance. In Japan's historical development experience and the contemporary developing countries: Issues for comparative analysis, ed. Kazushi Ohkawa and Yujiro Hayami. Tokyo: International Development Center of Japan.

Zysman, John, and Laura Tyson. 1983. American industry in international competition. Ithaca, N.Y.: Cornell University Press.

\section{Comment Takatoshi Ito}

The ground that this paper covers is very broad, ranging from 1600 to 1991 , from macro to micro, and from economics to politics. The paper is extremely

Takatoshi Ito is professor of economics at Hitotsubashi University and a research associate of the National Bureau of Economic Research. 
informative, reflecting Saxonhouse's long history of academic work on the Japanese economy and his recent experience on the Council of Economic Advisers dealing with Japan politically. Saxonhouse discusses various interesting topics, but I will limit my comments to two, intraindustry trade and the Structural Impediments Initiative (SII).

Intraindustry trade issues have been hotly debated by Robert Lawrence and Gary Saxonhouse. They do not disagree on the fact that Japan, along with Australia, is an outlier among industrial countries, with a very low intraindustry trade index. Lawrence argues that, with various factors controlled, the index remains low, explaining the fact as a reflection of either the Japanese market being closed or the Japanese minds being "closed." Saxonhouse argues that a special endowment pattern, a strong comparative advantage of manufacturing sectors, and a geographic location far away from other similar economies explain the low index. For the purposes of this debate, the recent rise of other Asian economies provides a good opportunity to judge which side is right. Because of geographic proximity, similarity in resource endowments, and close affinities among cultural heritages, Asian nations will leave Japan with no excuse for not increasing intraindustry imports, once these Asian economies become strong industrial powers, which should be some time in the not-too-distant future.

Put simply, it is not surprising not to see Lincoln Continentals on Japanese streets, but it would be surprising not to see Hyundai Excels and Sonatas; it is not surprising not to see Compaq computers in Japan, but surprising not to see any by Leading Edge; and it is not surprising not to see Philips color televisions, but surprising not to see GoldStars.

Japan placed itself in two dilemmas in the 1980s. First, Japanese policymakers like to deal with "free traders" in Washington. On the other hand, Japanese policymakers believe in long-term relationships, nonmarket (internal) labor markets, industrial policies, a no-bankruptcy policy, and policy interventions in general. Second, Japan has defended some policy measures on the grounds of its own "uniqueness." Rice should not be imported because rice for the Japanese is "unique." The Japanese are "unique" in their thrift and in the relationship between a paternalistic firm and its loyal employees. The uniqueness produced a high saving rate, high labor quality, and a stable relationship. These arguments were used against Japan by revisionists: "If you are so unique, why don't we treat you differently."

Regarding SII, it is puzzling why the United States asks Japan to become better and more efficient. It is not quite true that SII make Japan more efficient. From the Japanese point of view, U.S. demands are often treated as "foreign pressure" to shift from producer's surplus to consumer's surplus. 


\section{Comment Yun-Wing Sung}

I very much enjoyed Gary Saxonhouse's wide-ranging paper, which argues that the contrast in U.S. and Japanese productivity performance is extremely persistent and is independent of all but the most radical institutional change. While the paper gives plenty of historical evidence on the persistence of national economic performance, the case is overstated. Although the paper argues that national economic performances "may be surprisingly deep rooted," it does not elaborate on what those roots are from a theoretical standpoint. Without a theory of productivity growth, arguments based on historical evidence alone leave much to be desired. Saxonhouse seems to have an implicit theory of productivity in mind, although he does not spell out what it is. For example, the paper argues in the closing sections that the Structural Impediments Initiative (SII) is likely to improve Japan's competitiveness. If Saxonhouse is right, SII clearly represents a case where institutional change does affect competitiveness, and economic performance is not really so independent of institutional changes.

The closest that Saxonhouse comes to stating a theory of productivity is his statement that, "among the countries with the capacity to learn from foreign experience elsewhere, productivity bears a negative relation to the level of productivity performance," and he explains the contrast in U.S. and Japanese productivity growth performance by the countries' difference in productivity levels. However, such an explanation of productivity growth contradicts the central theme of the paper, that productivity performance is extremely persistent and deep rooted because differential productivity growth will converge over time and the superior productivity growth of Japan will disappear. In this case, Japan's superior productivity growth is only a historical accident: the destruction of World War II prevented the convergence of productivity levels of Japan and the United States.

It should also be noted that the East Asian newly industrialized countries (NICs) can certainly be classified as "countries with the capacity to learn from foreign experience elsewhere." However, according to Saxonhouse's data, Japan's productivity performance is superior to that of the East Asian NICs despite the fact that Japan's level of productivity is much higher. Productivity levels thus may not be a decisive factor in explaining productivity growth.

Saxonhouse cited his earlier work that Japan's lack of intraindustry trade can be explained by "Japan's distinctive factor endowments." For readers unfamiliar with Saxonhouse's previous work, it would have been much better if he had elaborated on what those material and human endowments are. Besides Japan's own endowments, it must be stressed that the lack of neighboring countries with a similar level of development also hampers Japan's intraindus- 
try trade. A substantial portion of intraindustry trade is intrafirm trade: the shipping of parts and components back and forth across borders of adjacent countries among subsidiaries of the same firm. Land access is a crucial element in the coordination of production across borders because turnaround time in transportation by land is much faster than that by sea. Japan's geographic insularity and the absence of highly developed economies adjacent to Japan combined to hamper Japan's intrafirm trade and intraindustry trade. It should be noted that Japan's recent wave of investment in the East Asian NICs has increased its intraindustry trade. However, the lack of land access between Japan and the East Asian NICs will continue to be an obstacle to intraindustry trade. 